\title{
The Development of Teaching Material in Writing Fable Story Texts with Children's Film Assistance for Grade VII in Junior High School 6 Tambusai Utara Rokan Hulu Riau, 2018/2019
}

\author{
Fransiska Parida D ${ }^{1}$, Amrin Saragih ${ }^{2}$, M.Oky Fardian Gafari² \\ ${ }^{1}$ Master Student in State University of Medan (Unimed), Indonesia \\ ${ }^{2}$ Lecturer in in State University of Medan (Unimed), Indonesia \\ fransiskaparida86@gmail.com
}

\begin{abstract}
This research deals with the development of teaching material in writing fable story texts with children's film assistance for grade vii in junior high school 6 Tambusai Utara Rokan Hulu Riau, 2018/2019. Teaching material of fable story text with children's film assistance are designed according to the development and age of students so that they can contribute to the emotional and moral development of students. The sample of this study were 32 students of seventh grade of in junior high school 6 Tambusai Utara Rokan Hulu Riau. The conclusion was teaching material with children's film assistance which developed can train students to learn independently with minimal help from the teacher. The role of the teacher is only as a facilitator who guides and directs students to learning fable story texts.
\end{abstract}

Keywords: development; teaching material; fable story text.

\section{Introduction}

Writing fable stories uses children's films as a tool of assistance in learning activities because in children's films aired various types of children's favorite so that from the various children's stories are expected students can bring new ideas. For example, in Finding Nemo, the film tells of a fish named Marlin who has a child named Nemo.

Marlin is a protective father who always makes Nemo feel he cannot do everything himself. However, Marlin's character is the key to the nature of parents who always look after their children. Not only that the flow and settings presented can attract students' imagination indirectly so students can find out the characteristics of each animal has that resembled human behavior.

Starting from where students can process it into a new story with new ideas that are more interesting as a basis for guided by animal behavior and animal life that has been shown through the Finding Nemo movie.

Fables in the form of animal-based stories that are human-like can be used as delivery of character values to students. Through stories we are able to educate, provide entertainment, shape children's personality, and guide children's emotional intelligence. In addition, through interestingly designed stories is an effective step to be more acceptable to students. This is due to media stories, especially fables, which are implicit in advising readers that readers (students) will unconsciously reap the moral message in the story. Children's films in the form of wellselected fables can be used as teaching materials that can build the character of a child (students), to prevent student behavior that cannot be underestimated. A lot of news about interschool student brawls is caused only by personal competition. This form of disagreement with government regulations was also manifested by student demonstrations that ended in anarchism. Through children's films, which are stories of fables, which have many exemplary stories, students are expected to have good behavior.

The relevance between writing fable texts is very much related to the help of children's films, in writing a fable text one must be able to master the concepts or ideas of writing to be written, conduct a study of gathering information as a concrete supporter in his writing. This is 
related to children's film-assisted activities, children's films themselves can respond through teaching materials that will be developed with children's films because responses are stimuli from within a person that encourage activities to occur in the learning process.

\section{Review of Literatures}

\subsection{Teaching Materials}

Teaching materials used in the learning process when developed according to the needs of teachers and students and properly utilized will be one of the important factors that can improve the quality of learning so that with the presence of teaching materials the role of teachers and students in the learning process shifts. Initially teachers were perceived as the only source of information in the classroom, while students were positioned as passive recipients of information from their teachers, with the teaching materials the teacher was no longer the only source of learning in the classroom

Broadly speaking, the teaching material or teaching material consists of knowledge, skills, and attitudes that students must learn in order to achieve predetermined competency standards. Tomilson (1998), explained that "material refer to anything which is done by writer, teacher or learners to provide source of language input and to exploit those source in ways which maximize the liklehood intake : in other word the supplying of informasion about and experience of language in ways design to promote language learning."

Based on the above understanding it can be concluded that teaching materials refer to whatever is done by the teacher for students in providing learning resources and utilizing these resources in a manner that is as much as possible delivering information about learning experiences by designing the teaching materials.

\subsection{Writing Fable Text}

Text is a learning tool in the 2013 curriculum, especially for Indonesian subjects. It can be stated that the 2013 curriculum emphasizes text-based learning. The terms text and discourse are considered the same and are only distinguished in the case that the discourse is more abstract and is a realization of the meaning of the text. Zainurrahman (2011: 128) states the term lexical meaningful text in the form of original words from the author or author. Whereas the Ministry of Education and Culture in Permana (2015: 23) Text is a set of language units, both oral and written, with a certain size, certain meanings, and certain goals. Text is seen as a unit of language that is contextually meaningful. Text is systematic and has a regular structure with elements that cannot be changed. If the element is changed, it will have a systemic impact. Text can be in the form of words, sentences, paragraphs, or discourses that have certain characteristics that are conventionally accepted, cognitively understood, then the textual characteristics themselves are called textures.

Relating to the experts above according to Priyatni (in Wulandari 2016: 16), the text is speech (oral) or written which serves to express ideas. Whereas Halliday and Ruqaiyah in Wulandari (2016: 17) mention that text is a path to understanding language. That is why, text is a language that is carrying out certain tasks in the context of a situation. All examples of living languages that take certain parts in the context of a situation are called text.

The word fable (fable) comes from Latin, namely fabulat, which means the story of animal life that behaves like a human (Ministry of Education and Culture 2014). Animal stories mean stories that have the main characters of animals. In the Big Dictionary of Indonesian 
Language, fable means a story that describes the character and mind of a human being who is the culprit played by animals (containing moral education and manners). Therefore animal stories are also called moral stories, namely stories that contain moral elements (good and bad human behavior) in the nuances of animals. Fable is indeed imaginary or does not really occur in the real world, so it is often referred to as an imaginary story, or a story that was written by the author (Sayuti 2009: 8). Compiling a moral story text (fable) must have a high imagination. The higher the imagination that the composer has, the better the story is produced.

\subsection{Text of Fables}

The curriculum of 2013 for text-based Indonesian subjects. According to Anderson (in Wulandari, 2016: 17) texts are grouped into two broad categories (genres), namely literary genres and factual genres. Literary genre aims to arouse the emotions and imagination of the reader or observer. Genre literature makes readers or listeners can laugh, cry, and reflect on themselves or purify themselves. Genre literature can be grouped into three types, namely narrative text (short, novel), poetic and dramatic. Narrative text aims to tell something, poetic text aims to express feelings or impressions of something, and dramatically aims to communicate ideas or experiences through action on stage. These three types can be in the form of oral or written. Factual genre aims to describe, tell, and convince readers or listeners. Some texts included in the factual genre include exposition text, descriptions, procedures, observational reports, and others.

The fable text according to Nurgiyantoro (2010: 22-23) has the character of figures of animals who can speak, behave, and behave as humans. In general, fables are not long, clearly contain moral teachings, and moral messages are actually usually placed at the end of the story. According to him, the story of fables is universal, meaning this story is found in various communities in the world. Usually there is a certain animal that is used as an idol, for example mouse deer, squirrel, ape, fox, and others depending on the selection of the owner. And unclear time of occurrence, but it usually points to the past. Another opinion emerged from Sugihastuti (in Suprihatin, 2015: 43) who argues that fables are also called persuasive texts. This persuasive text is primarily concerned with the recipient, the reader, or in terms of oral communication is the listener. It is this persuasive characteristic that often delivers fables as deductive, educational texts. In line with Sugihastuti, the opinion of Sulistyorini (in Suprihatin, 2015: 43) which states that fable text is certainly in the text contains moral and ethical values that can be followed. In it there are attitudes, speech, and character behavior can be taken moral values that can be taught to students.

\subsection{Children's Films}

Learning is a result of the interaction of stimulus and response. Someone has considered learning something if he can show changes in his behavior. Changes in behavior that occur must be conscious. Someone is said to learn if after learning activities he realizes that in him there has been a change in him a change has occurred. Stimulus is whatever is given by the teacher to students, while the response is in the form of reactions or responses of students to the stimulus given by the teacher. This stimulus is born from a stimulus stimulus theory, this theory basically says that effects are reactions to a particular situation. Thus, one can expect something or estimate something with a number of messages delivered through broadcasting.

According to Dwi Setiawan (2013: 14) This theory has three elements, namely (a) message (stimulus); (b) receiver (receiver); and (c) effects (response). The principle of stimulus response then raises a derivative theory called the hypodermic needle theory, namely the 
classical theory of the process of the effect of mass communication. In this theory, media content is seen as a drug injected into the audience's blood vessels, which is then assumed to react as expected. The stimulus stimulus theory also views that messages are perceived and distributed systemically and on a broad scale. Messages, therefore, are not addressed to people in their individual capacities, but as part of the community. To distribute messages as much as possible, technology users are a necessity, while individuals which is not affordable with message exposure, is assumed to be unaffected by the contents of the message.

\section{Research Methods}

This study was conducted in junior high school 6 Tambusai Utara Rokan Hulu Riau of seventh grade students. The implementation of this study was conducted in May to June 2019. The subjects were seventh grade students of junior high school 6 Tambusai Utara Rokan Hulu Riau in learning year of 2018/2019. The sample set in this study was seventh grade, which amounted to 32 students.

\section{Discussion}

The process of implementing the development of teaching materials in stage I is to bring up ideas / ideas by carrying out preliminary studies. The preliminary study conducted was by conducting a field survey (needs analysis) and literature survey. Based on the theory cited by Dahiya Sunita \& Ajeya Jha in the International Journal of Information Technology and knowledge (2011: 263), needs analysis is a process to determine the priority of educational needs, gather information and solve problems. Based on this theory, to determine the results of the field survey (Needs Analysis) obtained by distributing questionnaires to 2 teachers and 32 students in the school by first describing the definition of a children's film assisted module on the questionnaire to have an overview of the questions in the questionnaire submitted .

The results of the questionnaire distributed to teachers and students obtained the following conclusions.

1) All teachers $(100 \%)$ stated that they were not familiar with the teaching materials developed while most students $(84.3 \%)$ stated that they were not familiar with the teaching materials developed.

2) All teachers (100\%) stated that they had not used teaching materials developed in the learning process and $(87.5 \%)$ students stated that they had not used teaching materials developed according to the 2013 curriculum.

3) All teachers $(100 \%)$ stated that they needed teaching materials developed in the learning process and most students $(90.6 \%)$ stated that they needed teaching materials developed with the help of children's films in the learning process.

The next step is to conduct a literature survey. The results of the survey literature show that at present the teaching materials used by Grade VII Indonesian Language teachers in Junior High School 6, Rokan Hulu Riau are teaching materials produced by the Ministry of Education and Culture entitled "Indonesian Language" curriculum currently being implemented, that is 2013 curriculum revised in 2016.

The initial product development phase was carried out, namely the validation of the material content and design of the learning, product revision and assessment and suggestions by the teacher. Based on the stages of development of Borg and Gall (in Sanjaya, 2014: 136) 
this stage is the development stage to obtain input from material experts, design experts, and assessments and suggestions from Indonesian teachers.

The initial product of the instructional material developed was module-shaped teaching material in the fable story text material assisted by children's films for class VII in broad outline, including the following:

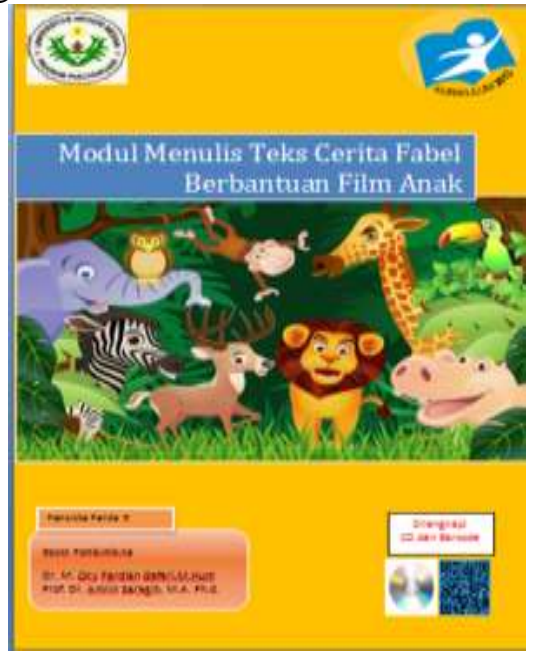

Figure 1. Module Cover

The module cover contains the identity of the module title, author and material to be developed. The module cover also contains pictures of animal collections showing fable stories. The purpose of making this image is so that the appearance of the module is more interesting and can represent the contents of the material in it. In addition to images, this module is combined with bright young colors that aim to stimulate students' enthusiasm in learning and reading the contents of the module. Color selection has also been consulted with design experts. The module cover also displays the two logos above, the Unimed logo and the 2013 curriculum logo. The curriculum logo indicates that this teaching material prepared by Unimed students and the 2013 curriculum logo indicates that the content of the material in this module has been adjusted to the competencies in the 2013 curriculum.
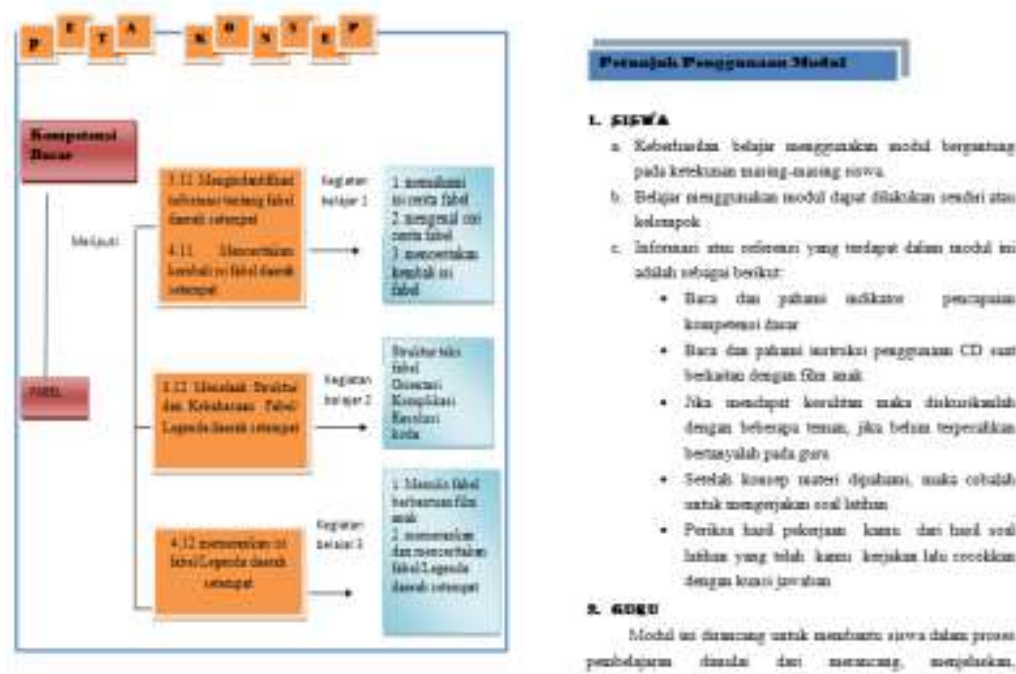

Figure 2. Initial Module Section 
The initial part of the module contains a concept map and module usage instructions. This concept map aims to make it easier for students to understand in advance the material and basic competencies to be learned from the module. By looking at the concept map students will find out what will be done in the module. Instructions for using the module contain how to use the module for both students and teachers. Instructions for students contain how students use modules and work on the activity sheets in the module. While the instructions for the teacher are about the role of the teacher in learning and the tasks that the teacher must do in using the module.

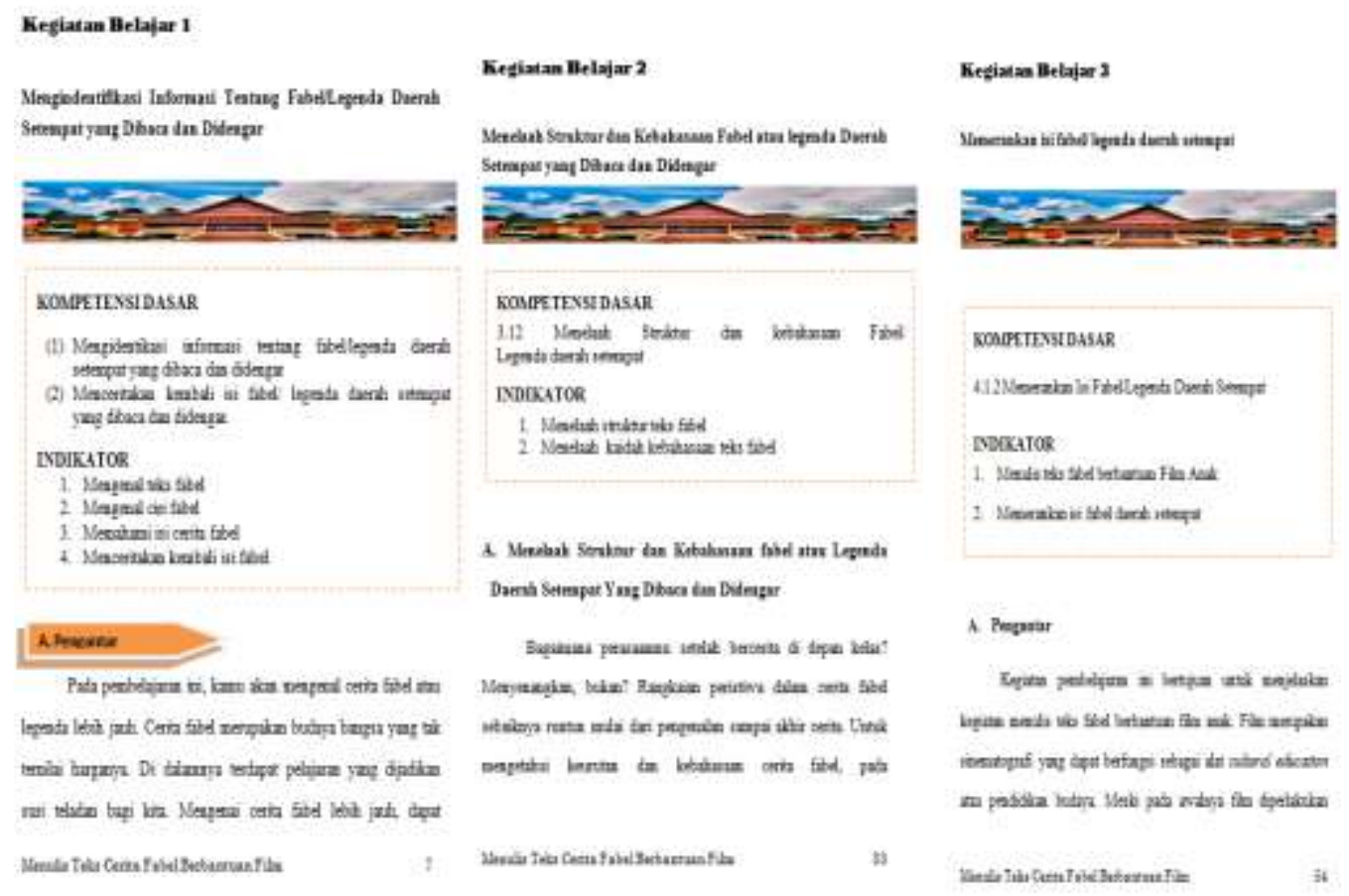

Figure 3. Module Contents section

The module content section includes learning activities that contain basic competencies and indicators of learning to be achieved. This module is designed with three learning activities with four basic indicators. In learning activities 1 student is required to be able to identify information about the fable / legend of the local area that is read and retell the contents of the local fable / legend that is read and heard. In learning activities 2 students are required to be able to study the structure and language of local fables / legends and finally in learning activities 3 students are required to be able to write and portray the contents of local fables / legends. 


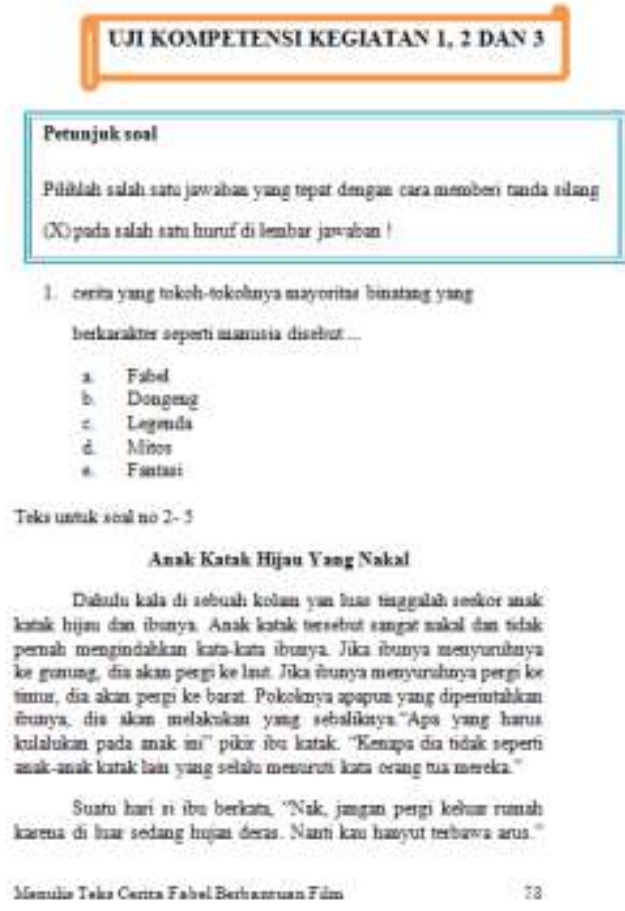

Figure 4. Module End Section

The final part of the module contains competency tests. The competency test contains questions about the material that has been studied in activities 1,2 and 3. This competency test aims to see the assignment of students to fable story text material. This competency test is made in the form of a multiple choice test consisting of 10 questions. At the end of the module the key Criteria to understanding test questions are also included, but students are allowed to see the Criteria key if they have finished working on the comprehension test questions.

The second thing that is done after the preparation is to do validation by material experts and design experts. Material validation was carried out by Mr. Prof. Dr. Ikhwanuddin Nasution, M.Sc. and Mr. Dr. Malan Lubis, M.Hum. While the design validation was carried out by Ms. Dr. Evi Eviyanti, M.Pd. and Dr. Surya Masniari Hutagalung, M.Pd.

The third thing that is done is conducting teacher assessment of the module. This assessment was carried out by two Indonesian language teachers at Junior High School 6 Tambusai Utara Rokan Hulu Riau. The results of the teacher's assessment of the fable story text module assisted by children were stated as "Very Good" with an average score of $95.8 \%$

The stages of product testing were carried out three times starting from individual trials (3 students), small group trials (9 students) and limited field trials (32 students). Individual testing was stated as "Very good with an average value of $86.1 \%$. The acquisition of the results of a small group trial was stated as "Very Good" with an average value of 91.2\%. Finally, the limited field trials obtained an average of $88.99 \%$ with the criteria of "Very Good".

The stages of developing a fable story text module assisted by a children's film have been carried out. Then the final product in the form of a module is ready to be used in Indonesian language learning, especially in fable story text material in class VII SMP.

The feasibility of teaching materials is obtained based on the results of the validation of the expert team, namely material experts and design experts after being validated, the 
product is tested on students individually, small groups and limited field groups. The following will be explained the feasibility test of teaching materials.

Validation by material experts is intended to find out the opinions of material experts about the feasibility of content, the feasibility of presentation and language on fable story text teaching materials assisted by children's films. This validation was carried out by Prof. Dr. Ikhwanuddin Nasution, M.Sc. who is a lecturer in culture at the University of North Sumatra and Mr. Malan Lubis, M.Hum. Who is a language lecturer at Medan State University? This validation is conducted to obtain quality teaching materials to improve Indonesian language learning at the junior secondary level, especially in fable story text material.

The results of the questionnaire showed that the feasibility aspects of the content of teaching material for fable story texts assisted by children's films were stated as "Very Good" with an average percentage of $87.5 \%$. Content is declared feasible because it is at an average value above $75 \%$. Data on the eligibility of the contents can be seen in table 4.1 below.

Table 1. Data on the Results of Material Validation on Content Feasibility

\begin{tabular}{|c|c|c|c|}
\hline Sub component & Assessment indicators & $\begin{array}{l}\text { Average } \\
\text { Percentage }\end{array}$ & Criteria \\
\hline \multirow[t]{2}{*}{$\begin{array}{l}\text { A. Conformity of } \\
\text { material with } \\
\text { KI and KD }\end{array}$} & $\begin{array}{l}\text { Completeness of material } \\
\text { Fable story text (structure, } \\
\text { linguistic rules) }\end{array}$ & 75 & Good \\
\hline & $\begin{array}{l}\text { Material breadth of fable story } \\
\text { text }\end{array}$ & 75 & Good \\
\hline \multirow[t]{7}{*}{$\begin{array}{l}\text { B. Material } \\
\text { accuracy }\end{array}$} & $\begin{array}{l}\text { Accuracy of concepts and } \\
\text { definitions of fable story texts }\end{array}$ & 100 & Very Good \\
\hline & Accuracy of facts and data & 100 & Very Good \\
\hline & $\begin{array}{l}\text { Accuracy of film and case } \\
\text { examples }\end{array}$ & 100 & Very Good \\
\hline & $\begin{array}{l}\text { Accuracy of images, films and } \\
\text { illustrations }\end{array}$ & 100 & Good \\
\hline & Accuracy of terms & 75 & Good \\
\hline & $\begin{array}{l}\text { Accuracy of notations, } \\
\text { symbols and icons }\end{array}$ & 75 & Good \\
\hline & Accuracy of references & 75 & Good \\
\hline \multirow[t]{5}{*}{$\begin{array}{l}\text { C. Proficiency of } \\
\text { Material }\end{array}$} & $\begin{array}{l}\text { Compatibility of material with } \\
\text { the development of science }\end{array}$ & 100 & Very Good \\
\hline & $\begin{array}{l}\text { Displays topics in films for } \\
\text { example fable story text }\end{array}$ & 100 & Very Good \\
\hline & $\begin{array}{l}\text { Pictures, diagrams and films in } \\
\text { everyday life }\end{array}$ & 100 & Very Good \\
\hline & $\begin{array}{l}\text { Use examples of cases or films } \\
\text { found in everyday life }\end{array}$ & 100 & Very Good \\
\hline & Library update & 75 & Good \\
\hline \multirow{2}{*}{$\begin{array}{l}\text { D. Encourage } \\
\text { curiosity }\end{array}$} & Encourage curiosity & 75 & Good \\
\hline & Creating the ability to ask & 75 & Good \\
\hline \multicolumn{2}{|l|}{ Average Amount } & 87,5 & Very Good \\
\hline
\end{tabular}


Table 2. The Percentage Criteria for the Emergence of Indicators on the Teaching Material of Fable Story Texts with Children's Film Assistance That have been developed

\begin{tabular}{|l|l|l|}
\hline No & Criteria & Score \\
\hline A & Very Good & $81 \% \leq \mathrm{X}<100 \%$ \\
\hline B & Good & $61 \% \leq \mathrm{X}<80 \%$ \\
\hline C & Medium & $41 \% \leq \mathrm{X}<60 \%$ \\
\hline D & Less & $21 \% \leq \mathrm{X}<40 \%$ \\
\hline E & Very Poor & $0 \% \leq \mathrm{X}<20 \%$ \\
\hline
\end{tabular}

(Sugiyono, 2011: 118)

The results of the questionnaire showed that aspects of the feasibility of presentation of teaching material of Fable Story Texts with Children's Film Assistance was stated as "Very Good" with an average percentage of $92.4 \%$. This means that the presentation of material in the module is declared feasible because it is above $75 \%$. Presentation of material is declared not feasible if you obtain an average score below $75 \%$. Data on the feasibility of presentation can be seen in table 4.2 below.

Table 3. Data on the Results of Material Expert Validation on the Feasibility of Presentation

\begin{tabular}{|c|c|c|c|}
\hline Sub Component & Assessment Indicator & $\begin{array}{l}\text { Average } \\
\text { Percentage }\end{array}$ & Criteria \\
\hline \multirow[t]{2}{*}{$\begin{array}{r}\text { A. Presentation } \\
\text { Techniques }\end{array}$} & $\begin{array}{l}\text { 1. Systematic consistency of } \\
\text { presentation in learning activities }\end{array}$ & 87,5 & Very Good \\
\hline & 2. Concept wrangling & 100 & Very Good \\
\hline \multirow{3}{*}{$\begin{array}{r}\text { B. Presentation } \\
\text { of Learning }\end{array}$} & 3. Involvement of students & 100 & Very Good \\
\hline & 4. Student-centered & 100 & Very Good \\
\hline & $\begin{array}{l}\text { 5. Stimulating students' ability to } \\
\text { solve problems through film }\end{array}$ & 100 & Very Good \\
\hline \multirow[t]{8}{*}{$\begin{array}{l}\text { C. Complete } \\
\text { Presentation }\end{array}$} & $\begin{array}{l}\text { 6. Examples of questions in each } \\
\text { learning activity }\end{array}$ & 87,5 & Very Good \\
\hline & $\begin{array}{l}\text { 7. Practice questions at the end of } \\
\text { each learning activity }\end{array}$ & 100 & Very Good \\
\hline & 8. Key Criterias to practice questions & 87,5 & Very Good \\
\hline & 9. Introduction & 87,5 & Very Good \\
\hline & 10.Table of contents & 100 & Very Good \\
\hline & 11. Glossary & 100 & Very Good \\
\hline & 12.References & 100 & Very Good \\
\hline & 13.Summary & 100 & Very Good \\
\hline \multicolumn{2}{|l|}{ Average Amount } & 92,4 & Very Good \\
\hline
\end{tabular}


Table 4. The Percentage Criteria for the Emergence of Indicators on the Teaching Material of Fable Story Texts with Children's Film Assistance That have been developed

\begin{tabular}{|c|l|l|}
\hline No & Criteria & Score \\
\hline A & Very Good & $81 \% \leq \mathrm{X}<100 \%$ \\
\hline B & Good & $61 \% \leq \mathrm{X}<80 \%$ \\
\hline C & Medium & $41 \% \leq \mathrm{X}<60 \%$ \\
\hline D & Less & $21 \% \leq \mathrm{X}<40 \%$ \\
\hline E & Very Poor & $0 \% \leq \mathrm{X}<20 \%$ \\
\hline
\end{tabular}

(Sugiyono, 2011: 118)

Language assessment on teaching material of fable story texts with children's film assistance is rated "Very Good" with an average percentage of $87.5 \%$. These results were obtained from questionnaires given to material experts. Language assessments are also considered feasible. This is because the average score on language assessment is above $75 \%$. Language assessments are declared not feasible if the average score obtained is below $75 \%$. Data on the results of material expert validation on the assessment of language on teaching materials can be seen in table 4.3 below.

Table 5. Data on the Results of Material Expert Validation on Language Assessment

\begin{tabular}{|c|c|c|c|}
\hline Sub Component & Assessment Indicator & $\begin{array}{l}\text { Average } \\
\text { Percentage }\end{array}$ & Criteria \\
\hline \multirow[t]{3}{*}{ Straightforward } & $\begin{array}{l}\text { Accuracy of sentence } \\
\text { structure }\end{array}$ & 75 & Good \\
\hline & Effectiveness of sentences & 75 & Good \\
\hline & Stiffness of terms & 87,5 & Very Good \\
\hline \multirow[t]{2}{*}{ Communicative } & Message readability & 87,5 & Very Good \\
\hline & Accuracy of language use & 75 & Good \\
\hline \multirow[t]{2}{*}{$\begin{array}{l}\text { Dialogical and } \\
\text { interactive }\end{array}$} & $\begin{array}{l}\text { The ability to motivate } \\
\text { messages or information }\end{array}$ & 87,5 & Very Good \\
\hline & $\begin{array}{l}\text { The ability to encourage } \\
\text { critical thinking }\end{array}$ & 87,5 & Very Good \\
\hline \multirow{2}{*}{$\begin{array}{l}\text { Conformity with } \\
\text { the level of } \\
\text { development of } \\
\text { students }\end{array}$} & $\begin{array}{l}\text { Conformity of students' } \\
\text { intellectual development }\end{array}$ & 100 & Very Good \\
\hline & $\begin{array}{l}\text { Conformity with the level } \\
\text { of emotional development } \\
\text { of students }\end{array}$ & 100 & Very Good \\
\hline \multirow{2}{*}{$\begin{array}{l}\text { Allegiance and } \\
\text { integration of mind } \\
\text { flow }\end{array}$} & $\begin{array}{l}\text { Allegiance and integration } \\
\text { between learning activities }\end{array}$ & 100 & Very Good \\
\hline & $\begin{array}{l}\text { Allegiance and integration } \\
\text { between paragraphs }\end{array}$ & 87,5 & Very Good \\
\hline \multirow[t]{2}{*}{$\begin{array}{l}\text { Use of terms, } \\
\text { symbols and icons }\end{array}$} & $\begin{array}{l}\text { Consistency in the use of } \\
\text { terms }\end{array}$ & 87,5 & Very Good \\
\hline & $\begin{array}{l}\text { consistency in the use of } \\
\text { symbols or icons }\end{array}$ & 87,5 & Very Good \\
\hline \multicolumn{2}{|l|}{ Average Amount } & 87,5 & Very Good \\
\hline
\end{tabular}


Table 6. The Percentage Criteria for the Emergence of Indicators on the Teaching Material of Fable Story Texts with Children's Film Assistance That have been developed

\begin{tabular}{|l|l|l|}
\hline No & Criteria & Score \\
\hline A & Very Good & $81 \% \leq \mathrm{X}<100 \%$ \\
\hline B & Good & $61 \% \leq \mathrm{X}<80 \%$ \\
\hline C & Medium & $41 \% \leq \mathrm{X}<60 \%$ \\
\hline D & Less & $21 \% \leq \mathrm{X}<40 \%$ \\
\hline E & Very Poor & $0 \% \leq \mathrm{X}<20 \%$ \\
\hline
\end{tabular}

(Sugiyono, 2011: 118)

Validation of design experts was carried out by Dr. Evi Eviyanti, M.Pd. and Dr. Surya Masniari Hutagalung, M.Pd. who is a lecturer at Medan State University. An assessment of this design was carried out to improve the quality of display of teaching material of fable story texts with children's film assistance. The results of the validation of the design experts indicate that the teaching material of fable story texts with children's film assistance. are in the "Very Good" category with an average percentage of 85.4. Data from design experts can be seen in table 4.4 below.

Table 7. Data on the Results of Validation of Design Experts on Teaching Materials

\begin{tabular}{|c|c|c|c|}
\hline Sub Component & Assessment Indicator & $\begin{array}{l}\text { Average } \\
\text { Percentage }\end{array}$ & Kriteria \\
\hline \multirow[t]{2}{*}{ Size } & $\begin{array}{l}\text { Suitability with ISO } 216 \\
\text { (A4, A5 and B5) standards }\end{array}$ & 87,5 & Very Good \\
\hline & Match size with material & 100 & Very Good \\
\hline \multirow[t]{5}{*}{ Cover design } & $\begin{array}{l}\text { Appearance of the layout } \\
\text { elements on the front, back } \\
\text { and back covers } \\
\text { harmoniously has a rhythm } \\
\text { and unity and is consistent. }\end{array}$ & 75 & Good \\
\hline & Showing a good center point. & 87,5 & Very Good \\
\hline & $\begin{array}{l}\text { The color elements of the } \\
\text { layout are harmonious and } \\
\text { clarify the function. }\end{array}$ & 87,5 & Very Good \\
\hline & $\begin{array}{l}\text { The composition and size of } \\
\text { the layout elements (title, } \\
\text { author, illustration, logo, } \\
\text { etc.) are proportional, } \\
\text { balanced, and in line with the } \\
\text { content layout (according to } \\
\text { the pattern). }\end{array}$ & 87,5 & Very Good \\
\hline & $\begin{array}{l}\text { The font size of the teaching } \\
\text { material title is more } \\
\text { dominant and proportional } \\
\text { than the size, the name of the } \\
\text { author. }\end{array}$ & 87,5 & Very Good \\
\hline
\end{tabular}




\begin{tabular}{|c|c|c|c|}
\hline & $\begin{array}{l}\text { The color of the title of the } \\
\text { teaching material contrasts } \\
\text { with the background color. }\end{array}$ & 87,5 & Very Good \\
\hline & $\begin{array}{l}\text { Don't use too many font } \\
\text { combinations. }\end{array}$ & 75 & Good \\
\hline & $\begin{array}{l}\text { Describe the content } \\
\text { teaching material and reveal } \\
\text { the character of the object. }\end{array}$ & 100 & Very Good \\
\hline Content design & $\begin{array}{l}\text { Shape, color, size, } \\
\text { proportion of objects } \\
\text { according to reality. }\end{array}$ & 87,5 & Very Good \\
\hline & $\begin{array}{l}\text { The placement of elements } \\
\text { of the layout is consistent } \\
\text { based on the pattern }\end{array}$ & 87,5 & Very Good \\
\hline & $\begin{array}{l}\text { Separation between clear } \\
\text { paragraphs }\end{array}$ & 87,5 & Very Good \\
\hline & $\begin{array}{l}\text { Printing and proportional } \\
\text { margins }\end{array}$ & 87,5 & Very Good \\
\hline & $\begin{array}{l}\text { The page margins are side by } \\
\text { side proportional }\end{array}$ & 75 & Good \\
\hline & $\begin{array}{l}\text { Spaces between text and } \\
\text { illustrations are appropriate }\end{array}$ & 87,5 & Very Good \\
\hline & $\begin{array}{l}\text { Placement of the title of } \\
\text { learning activities, subtitles } \\
\text { of learning activities, and } \\
\text { numbers of pages / folios } \\
\text { right }\end{array}$ & 87,5 & Very Good \\
\hline & $\begin{array}{l}\text { The exact placement of } \\
\text { illustrations and captions }\end{array}$ & 87,5 & Very Good \\
\hline & $\begin{array}{l}\text { Placement of decoration } / \\
\text { illustration as background } \\
\text { does not interfere with title, } \\
\text { text, page numbers. }\end{array}$ & 87,5 & Very Good \\
\hline & $\begin{array}{l}\text { Placements, subtitles, } \\
\text { illustrations, and captions do } \\
\text { not interfere with } \\
\text { understanding. }\end{array}$ & 75 & Good \\
\hline & Don't use too many fonts. & 75 & Good \\
\hline & $\begin{array}{l}\text { The use of letter variations } \\
\text { (bold, italic, all capital, small } \\
\text { capital) is not excessive. }\end{array}$ & 75 & Good \\
\hline & Normal text layout width. & 87,5 & Very Good \\
\hline & $\begin{array}{l}\text { Interline spaces in normal } \\
\text { text arrangement. }\end{array}$ & 87,5 & Very Good \\
\hline & Normal kerning space. & 87,5 & Very Good \\
\hline
\end{tabular}




\begin{tabular}{|l|l|l|l|}
\hline & $\begin{array}{l}\text { The hierarchy of titles is } \\
\text { clear, consistent and } \\
\text { proportional. }\end{array}$ & Good \\
\hline & $\begin{array}{l}\text { Signs of word cutting } \\
\text { (hyphenation). }\end{array}$ & 75 & Good \\
\hline $\begin{array}{l}\text { Able to reveal the meaning / } \\
\text { meaning of the object. }\end{array}$ & 87,5 & Very Good \\
\cline { 2 - 4 } $\begin{array}{l}\text { Accurate and proportional } \\
\text { forms in accordance with } \\
\text { reality. }\end{array}$ & 87,5 & Very Good \\
\cline { 2 - 4 } & $\begin{array}{l}\text { Creative and dynamic } \\
\text { Average Amount }\end{array}$ & $\mathbf{8 5 , 4}$ & Very Good \\
\hline
\end{tabular}

Table 8. The Percentage Criteria for the Emergence of Indicators on the Teaching Material of Fable Story Texts with Children's Film Assistance That have been developed

\begin{tabular}{|l|l|l|}
\hline No & Criteria & Score \\
\hline A & Very Good & $81 \% \leq \mathrm{X}<100 \%$ \\
\hline B & Good & $61 \% \leq \mathrm{X}<80 \%$ \\
\hline C & Medium & $41 \% \leq \mathrm{X}<60 \%$ \\
\hline D & Less & $21 \% \leq \mathrm{X}<40 \%$ \\
\hline E & Very Poor & $0 \% \leq \mathrm{X}<20 \%$ \\
\hline
\end{tabular}

(Sugiyono, 2011: 118)

Assessment carried out by material experts on teaching material of fable story text with children's film assistance consists of three aspects of assessment, namely aspects of content feasibility, language presentation and assessment feasibility. The results of the assessment on the aspect of content eligibility are stated as "Very Good" with an average percentage of $85.93 \%$. The assessment on the presentation aspect was stated as "Very Good" with a total percentage of $88.46 \%$. The results of language assessments according to material experts were stated as "Very Good" with a total percentage of $86.5 \%$. There are several suggestions from the validator listed in table 4.11 below

Table 9. Suggestions from the Material Validator

\begin{tabular}{|l|l|}
\hline No & Suggestion \\
\hline 1. & Strengthen the illustration \\
\hline 2. & Reference books that are more up-to-date and relevant \\
\hline 4 & Punctuation that does not match PUEBI \\
\hline
\end{tabular}

The assessment carried out by design experts is intended to improve the quality of display modules. Validation results by design experts were stated as "Very Good" with a total percentage of $89.1 \%$. Suggestions from the design experts' validators both in writing and verbally are generally listed in the following table 4.12 .

Table 10. Suggestion from Design Validators

\begin{tabular}{|l|l|}
\hline No & Suggestion \\
\hline $\mathbf{1}$ & Use shapes that are too crowded \\
\hline $\mathbf{2}$ & Fonts and module page size \\
\hline $\mathbf{3}$ & Cover module, the unimed symbol should be located at the top \\
\hline
\end{tabular}


The stages of testing teaching materials were carried out in 3 processes, namely individual trials, small group trials and limited field trials. Product trials were conducted to identify shortcomings of teaching material of fable story texts with children's film assistance.

The results of individual trial assessments are stated in the "Very Good" category with a total percentage of $86.1 \%$. Individual trials were carried out to determine students' initial responses to teaching materials before conducting small group trials. The results of the assessment of material indicators are stated as "Very Good" with an average percentage of 81.66\%. Language indicators $87.5 \%$ with "Very Good" category and indicators of $90 \%$ interest in the "Very Good" category. This teaching material of fable story texts with children's film assistance according to the needs of students.

\section{Conclusion}

The use of fable story text teaching materials with children's films assistance can improve student learning outcomes in learning fable story texts. Teaching material of fable story text with children's film assistance are designed according to the development and age of students so that they can contribute to the emotional and moral development of students.

Teaching material with children's film assistance which developed can train students to learn independently with minimal help from the teacher. The role of the teacher is only as a facilitator who guides and directs students to learning fable story texts.

\section{References}

Amri, Sofan. 2013. Pengembangan dan Model Pembelajaran dalam Kurikulum 2013. Jakarta: Prestasi Pustaka Karya

Atikah Nurul Asdah. 2014. "Kemampuan Membaca Memahami Teks Cerita Fabel (Moral) Siswa Kelas IX SMP Negeri 1 Makassar”. Skripsi.

Bahri, khalikul. 2017. Dampak film kartun terhadap tingkah laku anak (Studi Kasus pada Gampong Seukeum Bambong Kecamatan Delima Kabupaten Pidie). Skripsi

Cangara, Hafied. 2010. Pengantar Ilmu Komunikasi. Jakarta :Raja Grafindo Persada.

Daryanto, dwi cahyono, aris \& Purwanto, Djandji (Ed). 2014. Pengembangan prangkat pembelajaran (silabus, RPP, PHB, Bahan Ajar). Yogyakarta: Gava Media.

Depdiknas. 2008. Panduan Pengembangan Bahan Ajar. Jakarta: Depdiknas.

Fikar, Radhika. 2014. Keefektifan Penggunaan Model Example Non-Example Dalam Pembelajaran Menulis Teks Fabel Pada Siswa Kelas VIII SMP Negeri 6 Magelang. Skripsi

Hamdani.2011. Strategi Belajar Mengajar. Bandung : Pustaka Setia.

Kemendikbud. 2014. Bahasa Indonesia Wahana Pengetahuan SMP/MTs Kelas VIII. Jakarta: Purkurbuk, Balitbang, Kemendikbud

Kemendikbud. 2013. Buku Guru Bahasa Indonesia Ekspresi Diri dan Akademik. Jakarta : Politeknik Negeri Media Kreatif.

Kosasih, Engkos. 2017. Jenis-jenis Teks Analisis Fungsi, Struktur, dan Kaidah serta Langkah Penulisannya. Bandung: YRAMA WIDYA

Karsa, Indra Satya. 2006.Mengenalkan Anak pada Dunia Film. Jurnal Mediator Vol 7 No.2

Munadi, Yudhi. 2008. Media Pembelajaran: Sebuah Pendekatan Baru. Jakarta: Gaung Persada Press 
Mustafa Devy Anggraeny Ina. 2016. pengembangan bahan ajar pembelajaran menulis cerita berbasis pendekatan proses bagi siswa SMP. Prosiding Seminar Nasional Inovasi Pendidikan Inovasi Pembelajaran Berbasis Karakter dalam Menghadapi Masyarakat Ekonomi ASEAN

Nana Sudjana \& Ahmad Rivai. (2002). Media pengajaran : penggunaan dan pembuatannya. Bandung: Sinar Baru Algensindo.

Nurgiyantoro, Burhan. 2010. Teori Pengkajian Fiksi. Jogjakarta: Gajah Mada Unversity Press.

Permana dani lutfianto. 2015. Peningkatkan Keterampilan Menyusun Teks Cerita Moral (Fabel) Dengan Teknik Quantum Writing Pada Siswa Kelas Viii G Smp Kesatrian 1 Semarang Sk. Skripsi

Prastowo, Andi. 2014.Panduan KreatifMembuat Bahan Ajar Inovatif. Yogyakarta: Diva Press.

Qostantia, Lia Noviana. 2017. Bahan Ajar Menulis Cerita Fabel Dengan Stimulus Film Finding Nemo. jurnal Pendidikan: Teori, Penelitian, dan Pengembangan Volume: 2 Nomor: 3

Saepudin, Enceng. 2015. Tingkat Budaya Membaca Masyarakat. jurnal kajian informasi \& perpustakaan vol.3/no.2.

Setiawan, Dwi. 2013. Televisi sebagai Media Pendidikan. Yogjakarta: Pustaka Belajar.

Sugiyono. 2015. Metode Penelitian \& Pengembangan Pendidikan Research and development untuk bidang pendidikan manajemen sosial teknik. Bandung: Alfabeta.

Suprihatin. 2014. Pengembangan Bahan Ajar Teks Fabel Yang Bermuatan Kisah Teladan Upaya Menumbuhkan Karakter Dengan Pendekatan Saintifik Bagi Peserta Didik Kelas VIII SMP/MTs. Skripsi

Sri Hariani. Penggunaan Media Film Kartun Untuk Meningkatkan Keterampilan Menyimak Cerita Di Sekolah Dasar. Jurusan Pendidikan Guru Sekolah Dasar Universitas Negeri Surabaya

Sufanti, M. (2010). Strategi Pengajaran Bahasa dan Sastra Indonesia. Surakarta: Yuma Pustaka

Tegeh, Imade at el. 2014. Model Penelitian Pengembangan. Yogyakarta :Graha Ilmu.

Teguh Trianton. 2013. Film Sebagai Media Belajar. Yogyakarta : Graha ilmu

Tomlinson. Brian. 2011. Materials Development in Language Teaching. Cambridge. University Press

Waluyanto. 2006. Perancangan Film Kartun Berbasis Sel (Cel Animation), (Online), (http://www.tokoanimasi.com), accessed on 27 January 2019 